\title{
The Integration of Ethnopedagogy in Science Learning to Improve Student Engagement and Cultural Awareness
}

\author{
Yuli Rahmawati ${ }^{1, *}$, Achmad Ridwan ${ }^{1}$, Ucu Cahyana ${ }^{1}$, Tyaswati Wuryaningsih ${ }^{2}$ \\ ${ }^{1}$ Department of Chemistry Education, Universitas Negeri Jakarta, Indonesia \\ ${ }^{2}$ SMPN 4 Bolo, Indonesia
}

Received November 18, 2019; Revised January 2, 2020; Accepted January 13, 2020

Copyright $@ 2020$ by authors, all rights reserved. Authors agree that this article remains permanently open access under the terms of the Creative Commons Attribution License 4.0 International License

\begin{abstract}
This paper presents a study in applying ethnopedagogy by combining cultural learning and science education to assess the effect on student engagement and their cultural identity. This study stimulates students to care for their own ethnic identity, history and culture under modern era of social instability. The cultural identity itself can construct personal identity like the self concept and self esteem [51]. It is particularly essential for multicultural population of Indonesia with 633 ethnic groups. Ethnopedagogy approach has the function of supporting and protecting national values. The study involved 25 grade 7 junior high school students in Bima undertaking a project to create a model of the solar system. The study integrated indigenous knowledge and cultural practices related to the solar eclipse from the Bugis, Tidore, Yogyakarta, Solo, and Bima regions of Indonesia. A qualitative research method was applied to gather data using reflective journals, interviews, worksheets and a science test. The results show that integrating ethnopedagogy in science learning engages students in learning about their culture and develops problem-solving skills, while also improving information, communication, and technology (ICT) skills. An understanding of a scientific concept was developed through the learning experience, and the students developed their skills in communication and collaboration through completing the project in groups. Students faced the challenge of shifting their identity from passive to active learners and found the process to be a meaningful and enjoyable learning experience.
\end{abstract}

Keywords Ethnopedogogy, Science Learning, Scientific Phenomenon, Solar System Model Project, Student Engagement, Cultural Awareness

\section{Introduction}

Indonesia has more than a thousand cultural heritages [1]. Diversity is part of Indonesia's national identity, as stated by the motto "Bhinneka Tunggal Ika" (Unity in Diversity). Indonesian people live in diverse communities, representing many different cultures. Schools in Jakarta, as a capital city of Indonesia, for example, have students and teachers from different regions of Indonesia; therefore multicultural education is important due to the many unique and diverse cultures. In October 1994, UNESCO recommended multicultural education as a global commitment [2]. A multicultural education system encourages educational institutions to respond to the aspirations, needs, and demands of students from various backgrounds [3]

Ethnopedagogy can be an effective tool for connecting science with culture. According to [4] state that ethnopedagogy relates to the background of ethnic groups. Ethnopedagogy can help students develop the right attitude towards national cultural values [5]. In a study [6], students were challenged to rethink the importance of their peoples' traditional values in their own lives. According to [7] suggests that the purpose of ethnopedagogy is the attainment of syncretism or the reconciliation of two or more cultural elements or systems, with the modification of both.

Ethnopedagogy in science learning related to classification societies, culture-related physical phenomena, the cultural systems and to incorporate the values and the knowledge society [8]. Furthermore, it is a system of knowledge including an explanation of the natural world, which are used for predictive purposes and has practical application [9]. Etnopedagogy in science is a crossdisciplinary science that connects the human or cultural anthropology with science learning. The study is gained by 
instilling the local knowledge that is contained in the culture of an ethnic group or community. Local knowledge is derived from ideas of local communities about everyday life including traditional values, beliefs and cultures [10].

Learning science integrated with ethnopedagogy approach aims to reconstruct the cultural knowledge [11]. There are five things that can be lifted science based learning with cultural approach, i.e. the idea of a dynamic concept of the concept of culture as well as useful materials on the construction of culture, the historical thinking of society in organizing nature, holistic reasoning in various sectors of science and technology, specific terms of each community group [12]. The application of this learning can help learners to improve learning and preserve its identity [13].

This study integrated Indonesian cultural education with learning about the solar system in a junior high school science class. The Ethnopedagogy elements of the class examined scientific concepts from the perspectiveMore specifically, people in the Yogyakarta, Bima, Solo, Bugis, and Tidore regions have traditions relating to solar and lunar eclipses, which can be related to the scientific analysis of the solar system. Every citizen is unique and is a source of spiritual values, and all ethnic groups develop a distinctive moral and spiritual culture. Ethnopedagogical knowledge is the result of cognitive activity in a student expressed as learning the basic concepts of folk pedagogy. Such ethnopedagogical knowledge reflects basic patterns and relationships that exist in nature and society, the violation of which creates negative and irreversible processes. Ethnopedagogical knowledge involves the interaction and interrelation of society with the natural environment, with a scientific basis of environmental management [8].

Student engagement as the focus of the study is considered as the amount of physical and psychological energy students devote to the academic experiences [14]. Student engagement is demonstrated by the expression of opinions, attitudes, and behaviors [15] and has been demonstrated as a key element in improving student performance [16-18] Highly engaged students are intrinsically motivated to invest in learning, attend classes, and participate in study activities. They are curious, ask questions, and enjoy learning-challenges. Vigorous and dedicated students are energetically immersed in their studies, which leads to success [19]. The curriculum and learning activities should have the following three characteristics to improve student engagement: (1) Relevancy: teachers should introduce topics that connect with students' interests and concerns; (2) Responsibility: teachers should allow students to have genuine control over what, why, how, and when they organize their learning; and (3) Reality: students should be tasked with solving real-life problems [20].

Students often find science as a difficult lesson [21] and are reluctant to engage in science learning. The classroom engagement greatly impacts student participation and performance. However, in conservative science classroom, content and material are hard through worksheets, lectures and reading out of a textbook. These monotonous ways have caused students to be disengaged in what they are learning. Students experience tough time paying attention, if they are enjoying and not engaged the lesson. Teachers need to change over their focus to a more interactive method. By allowing students to expropriate, students feel more self-directed and independent, leading their own learning [22].

Instilling an activity that attracts to students' affective domain can increase their engagement, interest and performance in science learning, which can develop their attitude toward science [23]. [24] argue that students' motivation and attitudes towards science and their beliefs as learners are significant for their science learning engagement and can bring positive effects on the quality and quantity of learning outcomes. Furthermore, providing students with appropriate opportunities and challenges to develop their skills can be considered one of the most significant ways of engaging them [25]. A challenge is suggested to be associated with positive emotions, dedication to the task and challenges[26]. In a science learning activity, students are more likely to indicate higher level of achievement when facing a hard challenge [27].

This study engaged students in project-based learning. Mitchell and Carbone [28] suggest that student engagement can be enhanced depending on the nature of the task. Learning activities develop students' engagement through their participation in the activities [29]. The learning activities in this study used multimedia and technology, such as powerpoint and projectors, to engage students and allow them to explore ways to present their learning [30,31]. Engagement does not mean core knowledge and traditional literacy should be discarded; rather, students want to learn in more engaging ways, while also understanding the learning process. They desire quality instruction delivered in socially, emotionally, and intellectually engaging ways [32]. School engagement affects students' positive feelings toward school [33] and if they do not feel engaged at school, they are likely to lose interest in studying [34]. For this reason, school engagement is a major factor which has both direct and indirect influences upon students' learning achievements [35].

Student interest and engagement in science lessons have been studied in previous research. According to [36], students' motivation, interest, and attitudes towards science, schools, and their beliefs as learners are important for their engagement in science learning and can positively affect the quality and quantity of learning outcomes. Fredericks et al. [16] suggest a framework for considering engagement that distinguishes between cognitive, behavioral, and emotional engagement; cognitive engagement refers to 
students' commitment to their learning; behavioral engagement represents students' participation in school, classroom, and after-school activities; and emotional engagement reflects students' reactions to peers, teachers, and schools.

Students' interest in science is a complex and diverse construct that is influenced by teachers' perceptions, the value of science as a discipline, enjoyment, and achievement [36]. Researchers have found that instructional and conceptual approaches to science education may affect students' attitudes, motivation, and perceptions of science as a discipline. The study stimulates students to care for their own ethnic identity, history and culture through science learning. It is particularly essential for multicultural population of Indonesia with 633 ethnic groups. Several surveys show that young people have lack of knowledge of their own culture, history, and language. The need for knowledge of ethno-culture integrated with science concept that contains historical, moral experience, and values is particularly significant for developing personal qualities that can enable students to relate and interact in a multicultural world.

There are some competencies that students must achieve with this learning process. Students must describe the motion of planets orbiting the solar system and describe the characteristics of the components of the solar system. Students must understand scientific phenomena involving science and technology, show an interest in science, support scientific inquiry, and be motivated to act responsibly towards natural resources and the environment.This study examined the influence of ethnopedagogy in engaging science students to learn about the solar system.

\section{Methods}

The study used a qualitative research methodology with multiple data collection methods consisting of reflective journals, interviews, and a science test. A quantitative analysis was not undertaken as part of this study. The qualitative data provided information on how the integration of ethnopedagogy developed students' engagement in learning about the solar system. According to [37], one of the basic characteristics of the qualitative research is based on the collections of descriptive data, which attempts to understand meanings given to contexts. Data analysis tends to be inductive in qualitative research [37]. There is no data collection or proof with the aim to confirm or deny hypotheses previously developed; instead, abstractions are developed when data are grouped. According to [38], data analysis in qualitative research tends to be conducted inductively using raw data, where detailed readings result in subjects, concepts, or models. Science learning activities were undertaken three times over two weeks.

\subsection{Participant}

Twenty-five Grade 7 science stream students of a public secondary school in Bima, West Nusa Tenggara wellknown participated in this study. The remaining ( 9 males and 16 females) students' responses were collected to analyse the improvement of student engagement and cultural awareness through the integration of ethnopedagogy in science education. They are 12-13 years old. They are originally from Bima region. It is hard for them to speak Indonesian, they usually speak their local language. Teacher centered was usually used as a learning method in their science learning.

\subsection{Data Collection}

The researchers conducted a semi-structured interview with science teachers and students, a class observation to understand the class culture, worksheets, reflective journal, and science test. Students were then given a worksheet containing questions about themselves such as their character, how they learn at home and school, their relationship with others in the class, and their culture. In the implementation phase, the data from reflective journals and field notes were collected through the science learning process. Students were divided into five groups to discuss separate articles on the solar system that integrated cultural practices from Bugis, Tidore, Yogyakarta, Solo, and Bima. Next, students were instructed to make a solar system model with materials such as clay, styrofoam, and watercolors. The students then presented and explained their model and the concept in front of the class. Finally, the data obtained through semi-structured interviews, the reflective journals, and the science literacy test were collected. The students reflected on the learning process regarding teamwork, their understanding of the relationship between culture and science, and the character traits they developed from the learning process.

The reflective journal was used to record information on students' perceptions of the learning activities and experiences. Field notes contained observations on how the integration of ethnopedagogy in the science project was conducted and students' science learning responses. Observations contained written descriptions about students recorded by the researchers. Semi-structured interviews were undertaken using open-ended questions to elicit information on students' impressions towards the science project and their science literacy. The interview activities took \pm 10 -15 minutes for each student and were recorded. The science literacy test, which included key science conceptual understandings, higher-order learning skills, and science in context, was also developed. Science in context was assessed by relating science knowledge to an environmental context. Higher-order learning was evaluated by students presenting and identifying superior questions and using a wide range of information sources. 


\subsection{Data Analysis}

Science conceptual understanding, science in context, higher-order thinking skills, and effective aspects were formed to code the data using narrative texts. The results were verified by checking the compatibility and consistency with other data. Data were grouped into code and analyzed using both inductive and deductive approaches for analyzing qualitative data [39]. An inductive approach was formed to code the data collected from the interviews, reflective journals, and field notes, while a deductive approach was used to code the data on the science literacy test according to the coding criteria identified by [40]. The data were reduced by selecting, focusing, grouping, and removing unnecessary items [40].

\section{Result and Discussion}

\subsection{The Integration of Ethnopedagogy in Science Learning}

Ethnopedagogy integrated with science in the learning applies five stages: self-identification, content integration, collaboration, dialogue, and reflection. This study implemented three meetings that focused on the solar system. The integration of ethnopedagogy and science learning stages is shown in the picture below.

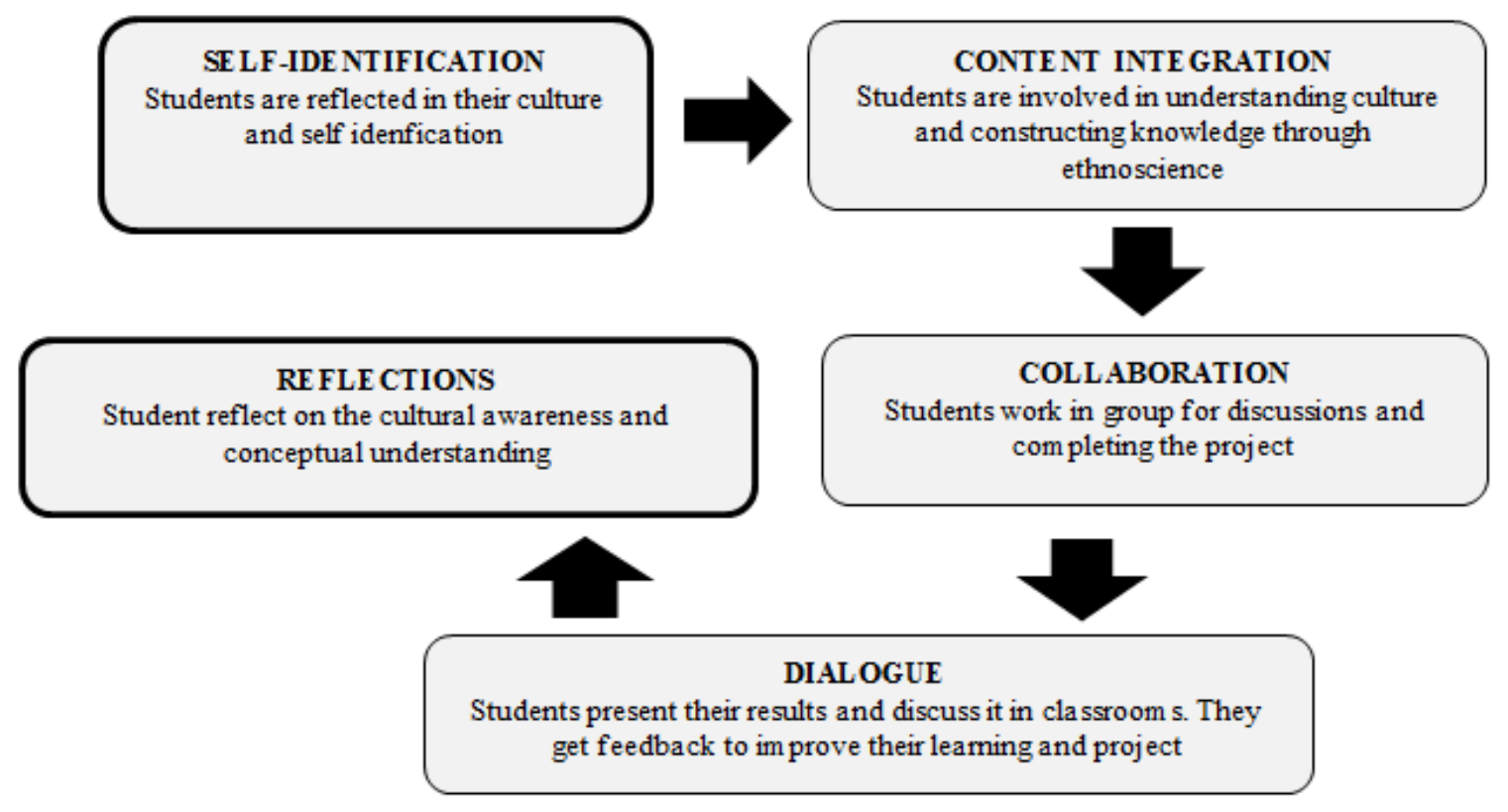

Figure 1. The Steps of Ethnopedagogy Approach 


\subsubsection{Self Identification}

The first stages in the study is self identification which students' background are identified. At this stage, teacher give a questionnaire which consists of learning styles, cultural background, and students' characteristis questions. Below is the example of student responds on selfidentification process:

Researche: Where are you from?

Student 8: The Bima region

Researcher: What do you know about your hometown? What is the culture like in your area of origin?

Student 8: Bima is well known for its food and drink and the local languange and culture. For example, Salama Loko, Peta Kapanca, and Compo Sampari.

Researcher: What do you think distinguishes you from people from other regions?

Student 8: Bima's food tastes sour but the other regions

I know prefer a spicy and sweet taste.

(Student 08 Worksheet, April 9, 2019)

Researcher: How do you describe yourself?

Student 11: I am a quiet person, but I like answering the teacher's questions.

Researcher: In your opinion, are you an active or passive student in the class?

Student 11: I am an active student because I always try to respond to the teacher.
Researcher: How is your relationship with people around you, especially with classmates?

Student 11: Good. When in a study group, I always present our task in front of the class.

(Student 11 Worksheet, April 9, 2019)

Student 08 self-identified using an explanation about their hometown. This student identifies as a Bima citizen, distinguishing them from other people from different regions. Student 11 identified their own personal characteristics and explained their positive behavior in the class as active knowledge builders, it can be one of the student engagement elements that can be increased to develop students lifelong learning skills [41].

\subsubsection{Content Integration}

Understanding cultures in the content integration and self-identification were the first steps in the study. The student groups discussed the various traditions performed by the five different regions in Indonesia during solar and lunar eclipses. The student groups comprised a mix of students from different backgrounds, to replicate the workplace in which team members must accept cultural differences [42]. At this stage, students read and dicussed articles that integrate science and culture that happened in their daily life. This table 1 below shown the ethnopedagogy articles on solar system concept in science.

Table 1. Integration of Science with Culture in the Solar System Project

\begin{tabular}{|c|c|c|c|}
\hline No & Culture & Traditions & Description \\
\hline 1 & $\begin{array}{l}\text { Balobe: dark } \\
\text { moon tradition. }\end{array}$ & $\begin{array}{l}\text { The community conducts activities } \\
\text { that involve looking for seafood } \\
\text { with sustainable tools. }\end{array}$ & $\begin{array}{l}\text { The tradition of finding fish or marine resources during the dark moon } \\
\text { with traditional and sustainable tools known as kalawai. }\end{array}$ \\
\hline 2 & $\begin{array}{l}\text { Tidore: dolo-dolo } \\
\text { eclipse tradition }\end{array}$ & $\begin{array}{l}\text { People in Tidore sound their musical } \\
\text { instruments together. }\end{array}$ & $\begin{array}{l}\text { This tradition aims to celebrate the lunar and solar eclipses. People in } \\
\text { Tidore believe that during a solar or lunar eclipse a giant creature, } \\
\text { named Suanggi, swallows the sun or moon. As a result, people sound } \\
\text { their musical instruments (tifas) to drive the creature away. }\end{array}$ \\
\hline 3 & $\begin{array}{l}\text { Bugis: rice } \\
\text { stealing tradition. }\end{array}$ & $\begin{array}{l}\text { Rice is stolen from a neighbor's } \\
\text { house and made into a powder for } \\
\text { smoothing over the body and } \\
\text { beautifying the face. }\end{array}$ & $\begin{array}{l}\text { The Bugis ethnic group steal rice around } 2 \text { palms from their neighbor } \\
\text { to face the lunar eclipse. This is accepted by all as it is a tradition. The } \\
\text { stolen rice is then processed into a powder. }\end{array}$ \\
\hline 4 & $\begin{array}{l}\text { Yogyakarta: the } \\
\text { Gejog Lesung } \\
\text { tradition to face } \\
\text { the solar eclipse. }\end{array}$ & $\begin{array}{l}\text { This traditional art from Yogyakarta } \\
\text { emerged as an expression of } \\
\text { gratitude for the abundance of the } \\
\text { rice harvest. }\end{array}$ & $\begin{array}{l}\text { Five or six people pound rice to a mortar with alu (a pounding wood), } \\
\text { causing a rhythm. Before the advent of grinding machines, mortar was } \\
\text { used to separate rice from the stem. There was a belief among the } \\
\text { ancient Javanese people that the solar and lunar eclipses occurred } \\
\text { because a giant known as Batara Kala ate the sun. They believed that } \\
\text { beating objects, including mortars, would cause Batara Kala to expel } \\
\text { the sun. Gejog Lesung is also associated with the belief of driving away } \\
\text { giants during lunar eclipses. }\end{array}$ \\
\hline 5 & $\begin{array}{l}\text { Solo: the Kala } \\
\text { Hayu tradition. }\end{array}$ & $\begin{array}{l}\text { This involves performing arts to } \\
\text { encourage the spirit of the darkness } \\
\text { to come during the total solar } \\
\text { eclipse. There is also an exhibition } \\
\text { of traditional utensils and cutlery so } \\
\text { that people understand the culture } \\
\text { and history. }\end{array}$ & $\begin{array}{l}\text { This culture believes that darkness is imagined when a solar eclipse } \\
\text { occurs; darkness does occur, but only for a moment. After darkness, } \\
\text { comes light, and humans return to their original activities. The animals } \\
\text { that hid when the solar eclipse took place come out of hiding and look } \\
\text { for food. The momentary darkness was considered to be the spirit and } \\
\text { is presented in the Kala Hayu (Marriage of the Great Kingdom) } \\
\text { performance. The performance begins with a parade and then an art } \\
\text { performance takes place, and a gratitude expression facing the solar } \\
\text { eclipse. In addition, there is an exhibition of traditional household } \\
\text { appliances that are increasingly used by the community. This } \\
\text { exhibition aims to illustrate the drastic cultural changes, and the spirit } \\
\text { of rural culture that once existed now has no trace. }\end{array}$ \\
\hline
\end{tabular}


Table 1 above shows how the cultural aspects of each region were integrated into the science concept (the solar system). After answering the worksheet, the student groups discussed their article explaining the traditions outlined in Table 1. Each group had a different article so after reading and summarizing their ideas, they presented their understanding of the article's content in front of the class. The reflective journal entries below demonstrate that students developed cultural understanding during the learning process. Research has shown that students' explanations of scientific phenomena are controlled by what they perceive from their cultural beliefs [43, 44] Ododo [45] suggested that students bring their cultural ideals and practices into science classes.

"A solar eclipse occurs because the Sun, Moon, and Earth are in one line where the moon is in the center. Bima's people believe that when a solar eclipse occurs, they should perform Kareku Kandel which makes sounds with alu and lesung. They believe that doing this can expel the spirits that cover The Sun."

(Student 05 reflective journal, April 15, 2019)

The results of the study show that the integration of ethnopedagogy in science learning can increase students' cultural understanding and identity and contribute to their understanding in science.

\subsubsection{Collaboration}

After presenting students' understanding on the articles given, they make a project based on the science concept (solar system). At collaboration stage, the activities help promote the problem-solving skills of participants by enabling them to work together on problems that are difficult to solve individually [46]. Collaborative learning that encourages socio-cultural interactions among students should be integrated into the curriculum to enhance student communication and intrapersonal skills that proved by the interview below.

Researcher: Do you think your group made the best project?

Student: I think not, I feel that our project needs a revision.

Researcher: Why?

Student: We did not have much time so the radius of each planet in the model was not correct.

Researcher: Do you think the project we made today is effective in improving our understanding of the solar system? Why?

Student: Yes, because we can study with the group. For example, we can determine the location of the planets and remind each other during the discussion.

Researcher: What is your role in the group when working on the project?

Student: I arrange the model planets and paint them.

(Student 15 interview, April 16, 2019)
Researcher: What is your role in the group?

Student: I am the leader.

Researcher: What is the leader's responsibility?

Student: The group leader must think about how the assignment is completed and then discuss and share the tasks in the group. We all have the responsibility to write, interact, give opinions, and lead the discussion.

(Student 13 interview, April 16, 2019)

The worksheet and student interview statements above demonstrate that this project developed students' ability to engage with one another, evaluate their ideas, monitor their work together, and manage failure while solving a problem. Furthermore, students also understood their role in the group and how to build collaboration skills. Students realized their own roles, and that they could finish the project by collaborating and communicating effectively.

\subsubsection{Dialogue}

The next steps in this study is dialogue where students presented their projects and explained their sub-topic in front of the class. Each group presented their model in front of the group to improve their communication skills. There were five groups with two different projects such as lunar eclipse model and solar system model. This learning activity was designed to improve students' communication skills and understanding of science concept. The figure 2 below shows that students try to explain the concept of solar system model (the sequence of planets) based on their discussion and book.

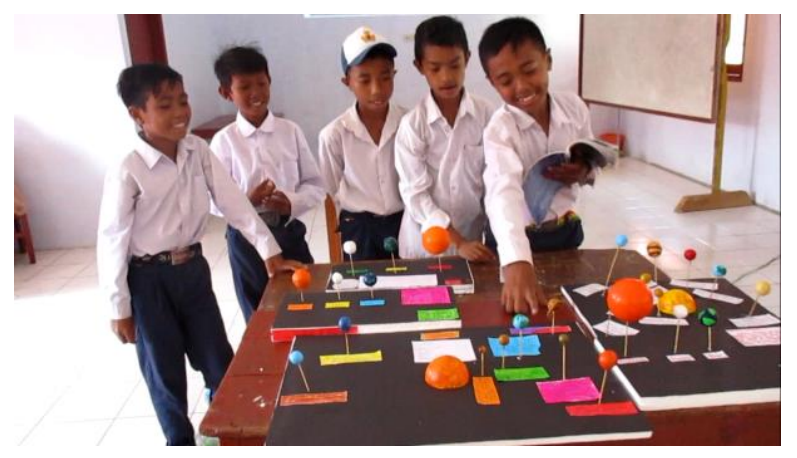

Figure 2. Student Presentation in Science Learning

Based on figure 2, there were students who present their projects after having group discussion and the other students should ask question and be more critical towards the explanation. Critical thinking was required in collaboration and dialogue phase as no instructions or clues were provided other than the pictures of the solar eclipse, lunar eclipse, and the solar system shown on the projector. Equipped with an understanding of the concepts prior to commencing the project, the students understood the correct sequence and color. Furthermore, the project facilitated deep learning; once the concept is understood, students can apply the theories and principles to the project and engage meaningfully in the task [47]. 


\subsubsection{Reflection}

The last stage in this study is reflection where the teacher as a facilitator direct the students to evaluate what they learned before. Students fill worksheet that ask about their changing after learning process. The interview below shows that student can reflect the integration and relation between solar system concept with their local traditions by making the project.

Researcher: What project did you do?

Student: The solar eclipse learning model.

Researcher: Is there any relation between the project and your culture?

Student: Yes, pregnant women must not go outside when there is a solar eclipse.

Researcher: Do you know why people should not go outside when there is a solar eclipse?

Student: It is because they will lose their sight.

Researcher: Do you understand the purpose of this project?

Student: Students will more have a better understanding of the solar system concept if we use a solar system model project. It is better than just listening to the teacher's explanation. I am so happy to do these learning activities because there is a group discussion.

(Student 12 interview, April 15, 2019)

In this project, students were encouraged to apply problem-solving skills in their life. Critical and analytical thinking was required to complete the activities, which will help students in decision making. According to [48], problem-solving is an important skill for students. Problem-solving in science helps students to solve problems in their daily life by applying their science skills and knowledge. Students' difficulties in problem-solving can be overcome through various activities and strategies [49]. Students who had problems in understanding how the solar system works improved their knowledge through making a solar system model. Through interviews, the study found that students who participated in the problembased learning activities successfully improved their ability to recall and retain information about solar system concepts and the related cultural aspects.

\subsection{Students' Engagement and Cultural Awareness in Science Learning}

This study found that the integration of Ethnopedagogy and Science Education can develop students' engagement and cultural awareness in learning science by science conceptual understanding, cultural identity and learning identity.

\subsubsection{Science Conceptual Understanding}

Science conceptual understandings test was developed by the key of science literacy as curriculum requirement. The test included the aspects of higher-order learning skills and science in context, as the criteria identified by [40]
Making the solar system projects helped the students to understand the sequence of the planets and the process of the solar and lunar eclipse. In the final meeting, the teacher provided an explanation of the solar system and the students were required to complete a test. Students also completed the reflective journal at the end of each meeting to evaluate their understanding throughout the learning process. Students' conceptual understandings were developed throughout the science learning process. They learned which celestial bodies exist in the solar system, as demonstrated by the following statements:

"I think there is the Sun, planet, comet, and eclipse in the solar system."

(Student 06 worksheet, April 16, 2019)

"A solar eclipse occurs when the Earth, Moon, and Sun are in a parallel position. The long distance between Earth and other planets makes them look like stars. Planets get their light from the Sun so they can shine. The effect of global warming is that the temperatures on Earth become hotter than average and there will be erratic changes, for example, this month should be summer but the rainy season is happening. We can tackle global warming by reducing the use of CFCs, replanting, stopping forest fires and reducing the use of vehicles." (Student 16 worksheet, April 16, 2019)

"The solar system studies how the Earth orbits the Sun and other celestial bodies such as Mercury, Venus, Mars, Jupiter, Saturn, Uranus and Neptune."

(Student 11 worksheet, April 9, 2019)

"In the solar system, we will study the circulation of The Moon towards Earth whose movements change during an interval of one month while the Earth rotates around the Sun in one year."

(Student 02 worksheet, April 9, 2019)

According to [50] stated that new knowledge construction in science is strongly influenced by the conceptions gained in prior learning. Physics, for example, relates to physical phenomena and its connection to students' daily lives, and students are encouraged to apply their science knowledge to their cultural traditions for meaningful learning experiences.

\subsubsection{Cultural Identity}

According to [51], cultural identity shows people's understanding of their values, norms, and characteristics that will lead and define their personal identity. Cultural identity can be defined as person's nature that includes beliefs, value in their environment [52].

Researcher: Do you understand the habits in your environment regarding the solar system? If yes, what are they?

Student: Yes. For example, if people in Bima want to plant seeds or sail they need to know the direction of the stars.

Researcher: What do you mean by the direction of the 
stars?

Student: If the stars are in the form of a kite, it means that seeds are ready to be planted.

Researcher: Do you feel more responsible for getting to know the culture in your environment and guaranteeing its sustainability? Why?

Student: I have become more responsible in regard to my culture and its need to be preserved because the generations of the future should know the past.

(Student 16 interview, April 9, 2019)

Researcher: What is your recommendation to make science learning fun?

Student: In the learning activities, there should be games and detailed explanations.

Researche: Has the science learning been fun?

Student: It's fun, because of the interaction with teachers.

I am excited because learning the solar system is connected with culture in several regions in Indonesia.

Those who did not know became aware of their own cultures.

Researcher: Do you better understand science if it is associated with culture or daily habits?

Student: Yes, because you can get to know other cultures and traditions. and others can learn about the Bima culture.

(Student 13 interview, April 9, 2019)

According to the conversation above, student has been done their local tradition activity through solar eclips signs. The local traditions related to the solar eclipse are held not only in Bima but also in other regions of Indonesia. Students' understanding of their cultural identity can motivate them to learn more about scientific phenomena to understand the factual reason behind every tradition. They have a responsibility to preserve their culture and traditions. Students were excited to integrate cultural concepts with science.

\subsubsection{Learning Identity}

Worksheet and reflection journal was filled by students at the end of the study. The results show that students' character have changed along the learning process. At first student said that she was shy and not brave to present her works but at the end, she can reflect her identity by writing it in reflective journal.

"I am a shy person, but in a group I can be brave in presenting our results and project in front of the class. Me and my friends always work together to complete our project or task. My job in the group is usually to find the solution, write it down, or present our group's result." (Student 09 worksheet, April 9, 2019)

At the end of the learning activities, the students wrote in their reflection by responding to statement is given. Examples of entries to the reflective journal at the final meeting are shown below.

Statement: I am embarrassed to ask.
Student 22: Yes, because I am afraid I will give the wrong answer and my friends will laugh at me.

Statement: I do not know about my culture.

Student 22: I only know the culture from Bima. especially the food such as Timbu and Minyak Sarua.

Statement: I am looking for information from several sources.

Student 22: Yes, I learn to find it in books or on the internet.

Statement: I play an active role in group.

Student 22: Yes, because in the group I made the project creatively.

(Student 22 Reflective Journal, April 16, 2019)

Statement: I am embarrassed to ask.

Student 12: I am not, because I want to know the correct answer and learn concepts that I do not understand.

Statement: I do not know about my culture.

Student 12: No, I know the culture in Bima such as Wura Bongi Monca and the Lenggo traditional dance, and Pangaha Bunga and Minasarua, the traditional food.

Statement: I am looking for information from several sources.

Student 12: Yes, I searched using the internet, books, and by asking experts.

Statement: I play an active role in the group.

Student 12: Yes, I am the leader in my group, and I answered the questions given by the teachers.

(Student 12 Reflective Journal, April 16, 2019)

Based on the reflective journal entries above, it can be concluded that students' engagement in the class was affected by their environment and peers. Some did not ask questions or participate in the class because they were afraid of being ridiculed. This shows that teachers should stipulate instructions and rules prior to starting the learning activities to set behavioral expectations. It is essential that students listen to the opinions of others first and do not interrupt their peers while they are speaking. This finding can be applied to improve students' self-confidence and self-esteem and increase their engagement in the class [53]. Finally, the ethnopedagogy should be applied in science education to develop students' engagement and cultural identity. The study shows that the integration of ethnopedaogy with science education can help student to find their identity, improve their science concept through the traditions and beliefs that happened in their daily life.

\section{Conclusions}

The Integration of ethnopedagogy in a solar system model project developed students' engagement, science conceptual understanding and cultural identity in science learning. Through this study, students get new experience in learning science linked to their local culture. Through the process, students were able to see the relevance and 
importance of science in their daily lives. This study found that ethnopedagogy developed student understanding of scientific concepts, awareness of cultural identity, problem-solving skills, collaboration and communication skills, and information, communication, and technology (ICT) skills. Throughout self-identification stage, the teacher as facilitator must pay attention to students' cultural backgrounds and character in order to engage students in the learning process. Students learned to feel a responsibility toward their culture. The main challenge of this study was the language barrier; the students rarely speak Indonesian but rather their local language, and local culture related to natural science that in accordance with the topic of learning. Thus, the integration of ethnopedagogy in science learning can provide meaningful learning for students, developed students' engagement, and cultural awareness, because students not only learn the concepts, but also learn how science concept implement in their local culture through project-making activities.

\section{Acknowledgements}

We would like to express our sincere gratitude to the Ministry of Research, Technology, and Higher Education, Indonesia for the grant, and Universitas Negeri Jakarta and SMPN 4 Bolo for their continued support.

\section{REFERENCES}

[1] Ministry of Education and Culture of Indonesia. Culture Statistics 2019. Center for Education and Culture Data and Statistics of the Ministry of Education and Culture, Jakarta, 2019.

[2] Rahim \& Rahmawaty. Signifikansi pendidikan multikultural terhadap kelompok minoritas. Jurnal Analisis, Volume XII, 2012.

[3] Banks, J.A., \& Banks, C.A.M. Multicultural Education: Issues and Perspectives. John Wiley and Sons, Hoboken, USA, 2010

[4] Klara, K., Baktiyar O., Sandygul K., Raikhan U., \& Gulzhiyan J. Ethnic pedagogy as an integrative, developing branch of pedagogy, Mediterranean Journal of Social Science, Vol 6, 612-619, 2015.

[5] Akhmetova S. Media Education Inthe Context of Development of Kazakhstan Journalism, World Applied Sciences Journal, Vol 29, 1050-1054, 2014.

[6] Toleubekova, R., \& Zhumataeva E. The role of ethnopedagogy in shaping positive attitudes towards traditional values of kazakh people among master's students majoring in education in kazakhstan. Problems of Education in the 21st Century, Vol 76, 834-846, 2018.

[7] Burger, H. G. Ethno-Pedagogy: A Manual in Cultural Sensitivity with Techniques for Improving Cross-Cultural Teaching by Fitting Ethnic Patterns (2d Ed) Albuquerque,
USA, 1971.

[8] Khusainov, Z.A,. Gaisin R.I., Biktimirov N.M., Valiev M.R., \& Gilemhanov I.R. Formation of Ecological Culture in the Aspect of Ethno Pedagogy, Mediterranean Journal of Social Sciences, Vol 6, 126-130, 2015.

[9] Wang, Ya-Hsuan. The Multicultural Science Literacy of Science Teachers in Taiwan, International Journal of Asian Social Science 3(9), 2052-2059, 2013.

[10] Dei, G. J.Sustainable development in the African context: Revisiting some theorical and methodological issues, Africa Development/Afrique et Développement, 97-110, 1993.

[11] Rist, S., \& Dahdouh-Guebas, F. Ethnosciences-A step towards the integration of scientific and indigenous forms of knowledge in the management of natural resources for the future, Environment, Development and Sustainability, 8(4), 467- 493, 2006.

[12] Aikenhead, G. Integrating Western and Aboriginal Sciences: Cross-Cultural Science Teaching, Research in Science Education, 31(3), 337-355, 2001.

[13] Lee, O. Culture and language in science education: What do we know and what do we need to know, Journal of Research in Science Teaching,38(5), 499-501, 2001.

[14] Astin, A W. Student involvement: A developmental theory for higher education, Journal of College Student Development 40(5), 518-29, 1999.

[15] Taylor, S. A., Hunter, G. L., Melton, H., \& Goodwin, S. A. Student Engagement and Marketing Classes, Journal of Marketing Education, doi: 10.1177/0273475310392542, 2011.

[16] Fredericks, J. A., Blumenfeld, P. C., \& Paris, A. School engagement: Potential of the concept, state of the evidence, Review of Educational Research, Vol 74, 59-109, 2004.

[17] Lee, J., \& Shute, V. J. Personal and social-contextual factors in $\mathrm{K}-12$ academic performance: An integrative perspective on student learning, Educational Psychologist, Vol 45, 185$202,2010$.

[18] Schaufeli, W. B., Martínez, I. M., Marqués-Pinto, A. M., Salanova, M., \& Bakker, A. B. Burnout and engagement in university students: A cross-national study, Journal of Cross-Cultural Psychology, Vol 33, 464-481, 2002.

[19] Salanova, M., Schaufeli, W. B., Martínez, I., \& Bresó, E.Ó. How obstacles and facilitators predict academic performance: The mediating role of study burnout and engagement, Anxiety, Stress \& Coping, Vol 23, 53-70, 2010 .

[20] Claxton, G. Expanding young people's capacity to learn, British Journal of Educational Studies, Vol 55, 1-20, 2007.

[21] Osborne, J., \& Collins. Pupils' views of the role and value of the science curriculum: A focus group study. International Journal of Science Education, Vol 23, 441-67, 2013.

[22] Stearns, S. What is the place of lecture in student learning today? Communication Education, 66(2), 243-245, 2017.

[23] Comfort, M.A. \& Alicia, C. Sustaining Student Engagement in Learning Science, The Clearing House: A Journal of Educational Strategies, Issues and Ideas, 87(6), 259-263, 
2014.

[24] Osborne, J., Simon, S., \& Collins. Attitude towards science: a review of the literature and its implications. International Journal of Science Education, 25(9), 1049-1079, 2003.

[25] Shernoff, D. J., Csikszentmihalyi, M., Schneider, B., \& Shernoff, E. S. Student engagement in high school classrooms from the perspective of flow theory. School Psychology Quarterly, 18(2), 158-176, 2003.

[26] Meijen, C., Jones, M. V., McCarthy, P. J., Sheffield, D., \& Allen, M. S. Cognitive and affective components of challenge and threat states. Journal of Sports Sciences, 31(8), 847-855, 2013.

[27] Grant, H., \& Dweck, C. S. Clarifying achievement goals and their impact. Journal of Personality and Social Psychology, 85(3), 541-553. 2003.

[28] Mitchell, I. \& Carbone, A. A typology of task characteristics and their effects on student engagement, International Journal of Educational Research, Vol 50, 257-70, 2011.

[29] Charles, M.T., Bustard, D. W., \& Black, M. Experiences of promoting engagement in game-based Learning, In: Proceedings of ECGBL 2009: 3rd European Conference on Games Based Learning, Academic Conferences Limited, pp 397-403, 2009.

[30] Dunleavy, J., \& Milton, P. What did you do in school today? Exploring the concept of Student Engagement and its implications for Teaching and Learning in Canada, Canadian Education Association, Toronto, 2009.

[31] Barnes, K., Marateo, R., \& Ferris, S. P. Learning Independence: New Approaches for Educating the Net Generation, Retrieved September 2010, from http://www. masternewmedia.org/news/2007/05/04/learning_independe nce_new_approaches_for.htm, 2007.

[32] Taylor, L., \& Parsons, J. Improving Student Engagement, Current Issues in Education, Vol 14(1), 2011.

[33] Mandernach, B. J. Effect of instructor-personalized multimedia in the online classroom, International Review of Research Open and Distance Learning, Vol10, pp 1-19, 2010.

[34] Niemi, A. M. What are effective strategies to support student engagement and learning? (Masters dissertation), Retrieved from https://www.archives.evergreen.edu/.../Niemi_A\%20 MITthesis\%202007.pdf. 2007.

[35] Dotterer, A. M. \& Lowe, K.. Classroom Context, School Engagement, and Academic Achievement in Early Adolescence, Journal of Youth and Adolescence, Vol 40(12), 1649-1660, 2011.

[36] Osborne, J., Simon, S., \& Collins, S. Attitude towards science: a review of the literature and its implications. International Journal of Science Education, Vol 25(9), pp 1049-1079. 2003.

[37] Bogdan, R.C., \& Biklen, S.K. Qualitative Research for Education: An Introduction to Theory and Methods. 4th ed. Boston, MA, Allyn and Bacon, 2003.

[38] Alasuutari, P. The rise and relevance of qualitative research. International Journal of Social Research Methodology, 13(2), 139-155, 2010.
[39] Pope, C., Ziebland, M., \& Mays, N. Analysing Qualitative Data, In: Qualitative Research in Health Care, Vol 320(7227), pp 114-116, 2000.

[40] Schwartz, Y., Ben-Zvi, R., \& Hofstein, A. Chemical Literacy: What Does This Mean to Scientists and School Teachers?, Journal of Chemical Education, Vol 83(10), 1557-1561, 2006.

[41] Gilbert, J. Catching the Knowledge Wave: Redefining knowledge for the post-industrial age, Education Canada, Vol 47(3), 4-8, 2007.

[42] Salk, J. E., \& Brannen M. Y. National Culture, Networks, and Individual Influence in a Multinational Management, Team Academy of Management Journal, Vol 43, 191-202, 2000.

[43] Okebukola, P.A.O. Beyond the Stereotype to New Trajectories in Science Teaching, Trade and Style Publishers, Abuja, 2002.

[44] Yip, D. Y. Promoting the development of a conceptual change model of science instruction in prospective secondary biology teachers, International Journal of Science Education, Vol 23(7), 755-770, 2001

[45] Ododo, O. M. Influence of Cultural Practice-Related Misconceptions on Achievement of Senior Secondary Biology Students in Zone C of Benue State, Nigeria, British Journal of Education, Society \& Behavioural Science, Vol 4(12), 1703-1715, 2014.

[46] Alves, J., Marques, M. J., Saur, I., \& Marques, P. Creativity and innovation through multidisciplinary and multisectoral cooperation, Creativity and Innovation Management, Vol 16, $27-34,2007$.

[47] Biggs, J., \& Tang, C. Teaching for Quality Learning at University, Open University Press, Maidenhead, 2011.

[48] Osman, S., Yang C., Abu, M. S., Ismail, N., Jambari, H., \& Kumar, J. A. Enhancing Students' Mathematical ProblemSolving Skills through Bar Model Visualisation Technique, International Electronic Journal of Mathematics Education, Vol 3(13), 273-279, 2018.

[49] Vula, E., \& Kurshumlia, R. Mathematics Word Problem Solving Through Collaborative Action Research. Journal of Teacher Action Research, Vol 1(2), 34-46, 2015.

[50] Ausubel, D.P. The acquisition and retention of knowledge: A cognitive view, Kluwer, Boston, 2000.

[51] Usborne, Esther \& Taylor, Donald. The Role of Cultural Identity Clarity for Self-Concept Clarity, Self-Esteem, and Subjective Well-Being. Personality \& social psychology bulletin. 36. 883-97. 10.1177/0146167210372215, 2010.

[52] Altugan, A.S. The relationsship between cultural identity and learning. Procedia - Social and Behavioral Sciences, Vol 186, pp. 1159 - 1162, 2015.

[53] Barak, M., \& Doppelt, Pupils Identify Key Aspects and Outcomes of a Technological Learning Environment, The Journal of Technology Studies, Vol 28, 22-28, 2002. 